City University of New York (CUNY) CUNY Academic Works

\title{
Agrammatic Verb Errors in Spanish Speakers and Their Normal Discourse Correlates
}

Jose G. Centeno

St. John's University - New York

Loraine Obler

CUNY Graduate Center

\section{How does access to this work benefit you? Let us know!}

More information about this work at: https://academicworks.cuny.edu/gc_pubs/55

Discover additional works at: https://academicworks.cuny.edu

This work is made publicly available by the City University of New York (CUNY).

Contact: AcademicWorks@cuny.edu 


\title{
Agrammatic verb errors in Spanish speakers and their normal discourse correlates ${ }^{1}$
}

\author{
José G. Centeno*, Loraine K. Obler \\ St. John's University, Jamaica, NY; 'City University of New York Graduate Center, New York, NY
}

\begin{abstract}
Agrammatic verb errors are characterized by a reliance on simple verb forms without elaborated inflectional markings. Yet agrammatism studies on verbs have not addressed the possible correlations that might exist between pre-morbid verb use patterns and agrammatic verb production, especially frequency in oral discourse. Spanish, a language with a highly inflected verb system, is a useful context to explore this interaction. This study investigated agrammatic and normal verb use for those Spanish verb tenses found in daily conversation (Silva-Corvalán, 1983; Bentivoglio and Sedano, 1992). We analyzed agrammatic verb performance in spoken discourse and a sentence repetition task, and compared it with verb use in normal spoken and printed narratives.

Findings suggested that the present was the most frequently used tense by both agrammatics and normals. The preterit, the second most frequent tense in normals, was similarly employed correctly by agrammatic subjects in the repetition task but was not present in their discourse. All other verb tenses, minimally found in normal texts, were similarly never produced in agrammatic discourse or minimally produced correctly in agrammatic sentence repetition. These results suggest that daily verb use patterns have a facilitating effect on verb use by Spanish-speaking agrammatic subjects. They agree with earlier arguments supporting the resistance of highfrequency words to errors in normal and aphasic speakers (Hall, 1954; Howes, 1964; Rochford \& Williams, 1984), possibly a reflection of an automatic, routinized, and overlearned nature due to their early acquisition (Schnitzer, 1989), and a significant degree of lexical strength (Bybee, 1985; 1995; Stemberger \& MacWhinney, 1986).
\end{abstract}

Agrammatism, a language disorder secondary to acquired brain damage, has been described as a simplification of sentence structure due to "a limited output use of the syntactic and morphological resources of the language" (Menn \& Obler, 1990, p.3). Specifically, oral expression in agrammatic speakers is limited by the presence of one or several morphosyntactic deficits such as the omission of free morphemes or functors (e.g., prepositions, conjunctions, and articles), bound morphemes (e.g., verb inflections), and modifying terms (e.g., adjectives and adverbs).

In terms of verb use, agrammatic English speakers have been observed to rely on simple verb forms, such as the uninflected infinitive and the -ing forms (i.e., go, going), at the expense of complex verb inflectional markings and use of the auxiliary (Goodglass, 1976). Similarly, in languages with a highly inflected verb system, 
agrammatic individuals display a reduction in the complexity of their spoken verb forms with a prominent use of infinitives, as reported in French speakers (Tissot, Mounin, \& Lhermitte, 1973; Nespoulous, Dordain, Perron, Jarema, \& Chazal, 1989); and number, gender, person, and tense errors as reported in both French and Italian speakers (Jarema \& Kehayia, 1992; De Bleser \& Luzzatti, 1994).

Indeed, Spanish, with a highly inflected verb system similar to that of other Romance languages, such as French and Italian, has been shown to have a similar agrammatic profile for verbs. For example, in a preliminary study by the first author summarized in Centeno (1996), a severely agrammatic Spanish Venezuelan speaker, AC, generated the following narrative after being asked what her work activities were before her CVA:

Cosia ... casa ... a trabajo ... algo ... a cocinar ... a fregar ... este ...

[he/she] was sewing... house... at work... something... to cook... to wash [dishes]... this ...

a cocinar ... yo cocino la casa ... cocinar bien.

to cook ... I cook the house... to cook well.

As in French and Italian agrammatism, verb use by the above agrammatic Spanish speaker was characterized by the reliance on simple verb forms without elaborated inflectional markings to indicate the time or person associated with the actions expressed by the verb. Verb forms in her narrative included the infinitive (fregar/to wash [dishes], cocinar/to cook), the present (cocino/I cook), and the imperfect (cosía/[he/she] was sewing).

Several explanations have been advanced to explain agrammatic verb errors in French and Italian. In French, Jarema and Kehayia (1992) argue that the mental organization of verbs might involve an uninflected stem to which those inflectional possibilities allowed for each stem of the verb can be appended. Their assertion is based on the errors for tense and aspect markers that agrammatic French-speaking subjects produced in repetition and sentence-production tasks involving one- or two-root French verbs. Error patterns led these authors to claim that "lexical storage reflects the internal morphological structure and idiosyncrasies of verbal lexical items" (p. 559). In this manner, one-root verbs (e.g., manger [to eat]: mang-) and their inflectional options would be stored in one common storage unit whereas two-root verbs (e.g., partir [to leave]: par- or part-) would have two separate, yet linked, storage units for each root and its respective inflectional options.

Jarema and Kehayia's investigation provided additional important evidence for the study of agrammatism. The variability in the types of substitutions generated by the subjects for the target inflections, for instance, the present and imperfect tenses for the past and future tenses for one-root verbs, and the infinitive for two-root verbs, demonstrated that the infinitive or the gerund are not the only verb forms to which agrammatic speakers might resort in their oral expression. Other inflections permitted by the wide range of inflectional possibilities in the paradigm of a particular verb can be erroneously accessed. Consistent with Jarema and Nespoulous (1984), who reported that the infinitive is not the only substituting form used by French-speaking agrammatics, Jarema and Kehayia's findings markedly contrast with the agrammatic reduction of verb use in English, a less inflected language than French, to two characteristic verb forms; the infinitive and -ing forms.

The inflected Italian verb system has also served as research tool to address the 
question of verb inflections in agrammatism. In an investigation of the required gender and number markings of the past participle in Italian verbs, De Bleser and Luzzatti (1994) observed that the rate of success exhibited by agrammatic Italian-speaking subjects depended on the syntactic complexity of a sentence. Agrammatic subjects performed better with simple sentences than in complex sentences in cloze tasks requiring the production of the appropriate participial inflection. In Italian, gender and number inflectional assignment for the past participle requires the interpretation of the grammatical features of an appropriate antecedent, such as a noun or a pronoun.

Based on the deficient inflectional marking of the past participle in complex sentences, De Bleser and Luzzatti claim that agrammatic speakers might not be able to access the full syntactic representation of the argument structure of verbs in complex sentences since the two subjects participating in the study used a minimal-distance solution or random selection to assign gender and number inflections to the past participle used in the sentence context. They place the possible locus of the impairment at the positional level in Garrett's (1980) sentence production model in which grammatical suffixes are mapped onto functional representations.

Only a very small number of studies has particularly addressed the production of verb inflections by agrammatic Spanish speakers. In fact, there is a considerable paucity in the aphasia literature on aphasic symptoms in Spanish speakers (see Ardila, 2001). Regarding verbs, Schnitzer (1989) attempted to provide some insight into the use of verbal inflectional markings by Spanish-speaking aphasics. In his study of an undifferentiated aphasic group of monolingual Spanish and bilingual Spanish-English Puerto Rican individuals, Schnitzer reported inflectional errors in the spoken modality for most of the grammatical and semantic features in the Spanish verb structure, which will be discussed later in this chapter. These findings, which included errors of tenseaspect, person, and number markings, led Schnitzer to support a regression to a Givonian "pragmatic" 2, "conversational interpretation" of language (p.140) to explain aphasic verb use.

Because Schnitzer's investigation employed an unselected subject population, we cannot delimit specific information concerning verb use by Spanish-speaking agrammatic individuals. Yet, his investigation provided an important observation in that it suggested that poor performance in some of the investigated tense-aspect forms, such as the future, conditional, and present perfect, might have resulted from their limited frequency in ordinary communication and the use of alternative verb forms to convey their meaning. For instance, he reports that the inflected future tense (e.g., comeré[he/she/it will eat]) is rarely used conversationally in Puerto Rican Spanish. Rather, the construction "ir $a^{\prime \prime}$ (to be going + infinitive) is generally used instead. This finding is consistent with observations of informal, spoken Spanish in Venezuela (Sedano, 1994).

Other studies have specifically addressed morphosyntactic agrammatic errors in Spanish. Reznik, Dubrovsky, and Maldonado (1995) analyzed the spontaneous narrative sample generated by an agrammatic Argentinean speaker. In particular, this speaker exhibited no morphological errors but difficulty with word order (e.g., " *encontré no a una hermana mi" [no encontré a mi hermana]/found no to a sister my [I didn't find my sister], p. 364) and clitic pronouns (" *hermano mío"[mi hermano]/brother mine [my brother], p. 363). Reznik et al. do not provide a theoretical explanation to account for the 
word order deficits in this agrammatic speaker but argue that, for clitic pronoun restrictions, Chomsky's Government Binding principles can have an explanatory value. In particular, clitic pronoun deficits seem to emerge when the speaker has to process null elements $(e)$ as in the expression "Pedro la entregó" (Pedro gave it). In syntactic terms, this expression can be represented as "Pedro $\mathrm{la}_{\mathrm{i}}$ entregó $e_{i}$ " in which there is a relationship between the clitic $l a$ and the null element $e$.

Other research on agrammatic Spanish verb errors invokes the role of morphological structure as a relevant factor. Based on results from a sentence repetition task (which were analyzed in a different fashion for this chapter), Obler, Harris, Meth, Centeno, and Matthews (1999) argue that agrammatic verb errors may stem from production difficulties involving the structural length of the verb inflection. Results showed that agrammatic Spanish speakers experienced more difficulty as the syllabic length of the inflectional affixes increased.

In this chapter, we demonstrate the role of discourse frequency as a facilitating factor in agrammatic Spanish verb use. We present evidence suggesting that agrammatic verb errors can reflect premorbid uses of verb forms when we compare agrammatic and normal verb use for those verb tenses occurring in daily conversation. We will begin with a description of the discourse characteristics of Spanish verbs. Then, we will present findings from the aphasia and Spanish language development literature suggesting the possible facilitating role of lexical frequency of occurrence in aphasic language use. Finally, we will discuss our study, its findings, and its possible implications for the understanding of verb use in agrammatism in Spanish speakers.

\section{Discourse Features of Spanish Verbs}

The Spanish verb system, like that of French and ltalian, is highly inflected. Spanish verbs encode several morphosemantic notions: tense, mood, aspect, person, and number. In addition, each Spanish verb involves a "thematic vowel", $a, e$, and $i$, easily recognized in the infinitive (e.g., tomar/to drink, comer/to eat, subir/to move up, to go up). According to their thematic vowel, Spanish verbs can be classified into first, second, and third conjugation classes depending on whether their inflectional endings follow the $-a r$, $-e r$, or -ir inflectional patterns, respectively. Also, Spanish verbs are subject to the stress-assignment rules of the language, generally carrying a strong-weak syllable pattern. For an in-depth discussion of these features, the reader is advised to refer to Centeno (1996), Qüilis and Hernández-Alonso (1990), and Stockwell, Bowen, and Martin (1965). Here, we focus on an additional factor having an impact on the use of Spanish verbs, namely, frequency patterns in daily discourse.

Some Spanish verb forms are employed more frequently than others in informal conversation, as shown by sociolinguistic research. Silva-Corvalán (1983) reported the prominent use of certain verb tenses in the narratives produced by Chilean and Mexican speakers. She observed that despite the frequent alternated use of the present [presente ${ }^{3}$, the preterite [preterito perfecto simple], and the imperfect [pretérito imperfecto] tenseaspect forms in spoken discourse, the preterite-present alternation emerged as the most prominent shift. Silva-Corvalán argued that, by bringing past events into the present time, it helped the speaker describe past events in a "more vivid and dramatic" (p. 775) 
manner, as if they were occurring in the present time in front of the narrator. Inspection of the language samples provided by Silva-Corvalan revealed that other tense-aspect forms, including the condicional and pretérito pluscuamperfecto, were produced by the speakers in conversation less frequently than the present, preterite, and imperfect.

Bentivoglio (1987) and Bentivoglio and Sedano (1992) provide similar evidence confirming the use of the above tense-aspect forms (i.e., presente, preterito perfecto simple, pretérito imperfecto, condicional, and pretérito pluscuamperfecto) and, in the case of Bentivoglio and Sedano (1992), utterances indicate the presence of an additional form, the preterito perfecto compuesto, in the informal spoken language samples of Venezuelan speakers. These tense-aspect forms used in informal conversation by Spanish speakers are summarized in Appendix A.

\section{Lexical Frequency of Occurrence and Aphasic Language Use}

Studies on agrammatic verb errors have not addressed the possible correlations that might exist between agrammatic verb use and pre-morbid verb use patterns, especially frequency in spoken discourse. There is evidence supporting the importance of frequency of occurrence for lexical items in normal language processing and aphasia. Specifically, high-frequency forms seem to be resistant to errors in normal language processing. For instance, Hall (1954) reported that high-frequency words are much easier to recall than low-frequency words in a free-recall task. In terms of aphasic language, Howes (1964) showed that aphasics favored the use of high-frequency vocabulary instead of low-frequency lexical items in their free speech. Rochford and Williams (1965) found that the effect of frequency of usage favoring high-frequency words held for both verbs and nouns in a pictured naming task given to aphasics. Goodglass (1976) and Stemberger (1984) suggest the possibility that the hierarchy of loss errors in agrammatism might be sensitive to usage frequency patterns. In particular, the plural suffix $-s$, the $3 \mathrm{sg}$. pres. suffix $-s$, and the possessive clitic $-s$ are differentially affected in this order. The plural, the most frequent, is the least affected; the present, with an intermediate frequency, is moderately affected; and the possessive, the least frequent, is the most commonly affected. Finally, Miceli and Caramazza (1988) found that an Italian agrammatic speaker's word repetition was better for frequent units than for infrequent units.

Some pyscholinguistic principles have been proposed to account for the resistance of high-frequency vocabulary to errors. Stemberger and MacWhinney's (1986) analyses of spontaneous speech errors showed that high-frequency inflected forms are less susceptible to at least one type of inflectional error - the no-marking error (e.g., "need" for "needed"). These findings led the investigator to argue that frequency is encoded in terms of "strength" (p. 24) or degree of semantic or pragmatic activation which protects the item from error. Hence, high-frequency items, involving higher activation levels than low-frequency items, would be less vulnerable to phonological and inflectional errors than those forms with a low frequency.

In line with Stemberger's argument, Bybee $(1985,1995)$ similarly advances the notion of "strength" in morphological processing in the lexicon. To Bybee, an item that occurs frequently in actual language usage would have a high lexical strength, would be 
easy to access, have more morphological fusion, and exhibit an autonomy that makes it resistant to change and prone to semantic independence.

In sum, frequency of occurrence, not investigated in earlier studies of agrammatic verb errors, might seem to be an important factor. The above discussion illustrated that high- and low-frequency lexical items, involving different degrees of morphological fusion, have a different "strength" to resist impairment and, in turn, could result in different production patterns in agrammatic expression.

\section{Frequency Patterns in Spanish Acquisition and Discourse}

The relationship between verb acquisition and discourse patterns can also be incorporated in the study of agrammatic verb impairment. In particular, the frequency patterns observed during the development of verb inflections in Spanish-speaking children and their usage patterns later observed in the discourse of Spanish-speaking adults deserve our attention. It is possible that the frequency parallels observed in early acquisition and maintained in adult language usage might have an important role in facilitating the production of certain verb forms. In this regard, grounded in Givon's (1979) proposal on a language performance, Schnitzer (1989) advances the notion that early acquisition and frequency of use might interact. Early emerging forms prominently occurring in daily conversation might be associated with an "overlearned", "automatic", and "routinized" processing (p. 6, 136) thus being able to withstand linguistic dissolution in aphasia.

Descriptive studies looking at the sequential acquisition of grammatical morphemes in Spanish appear to be in agreement that the first tense and inflection used by Spanishspeaking children is the present tense and the third person singular as suggested by the use of forms such as "Habla"[he/she speaks], "Va"[he/she goes, and "Tiene"[s/he has] (Gonzalez, 1980; Kvaal, Shipstead-Cox, Nevitt, Hodson, \& Launer, 1988; Maéz, 1981).

Findings on narrative production in normal Spanish-speaking children and adults are consistent with the above observations. Based on spoken narrative texts in children and adults, Sebastián and Slobin (1994) reported findings supporting Silva-Corvalán's (1983) observations on oral narratives in Spanish-speaking adults. These authors showed that, despite an oscillation between the present and the past in choice of dominant tense until age 5 , the present stabilized as the most frequently used tense in the narrative of the 9-year-old children, the oldest group of children in the study, as it was in adult discourse. Similarly, Bybee's (1985) survey of Spanish adult narratives suggests that the four most frequent verb forms in Spanish correspond to singular inflections for the present and past tenses in the indicative mood (presente and pretérito perfecto simple in this study).

In sum, early acquisition patterns in Spanish verb tenses seem to be reflected in the frequency of adult spoken verb usage. Consistent with the argument suggesting a resiliency of early-acquired, frequently-used language forms to impairment (Schnitzer, 1989), studies on agrammatic verb deficits should also consider the implications that these observations might have on the facilitation of the production of certain verb inflections. In particular, for this study, we predicted that those verb tenses most frequently employed in daily discourse, namely, presente and pretérito (Silva-Corvalán, 
1983), with an early acquisition history, would similarly occur in agrammatic utterances for their resilient nature to aphasic breakdown.

\section{Investigation of Verb Errors Method \\ Normal Speakers}

Samples: In order to determine frequency of verb tenses in daily use, two types of samples, were employed, namely, newspaper texts and soap opera dialogues. These samples were selected for their average level of linguistic complexity. Specifically, fifty randomly-selected paragraphs from different Venezuelan newspaper articles and 45 minutes of spoken dialogue from three different popular Venezuelan soap operas were analyzed for the verb forms employed in their written and spoken discourse, respectively.

Procedures and Data Analysis: Each time a verb tense was used in each text for newspaper articles and soap operas was counted to calculate an overall total and percentage of occurrence for each verb tense (Table 1).

Agrammatic Speakers

All subjects participating in the tasks below were monolingual Spanish speakers with an average level of education. They were clinically categorized as agrammatic using the guidelines provided by the Boston Diagnostic Aphasia Examination (Goodglass \& Kaplan, 1974) and the Cross-Language Agrammatism Study (Menn \& Obler, 1990). Their speech was halting but intelligible. Their comprehension was adequate for conversation and the tasks presented. All subjects had a single, unilateral, left-sided, cortical lesion. They had no history of alcohol or substance abuse, psychiatric illness, or learning disabilities. In addition, their hearing was assessed to be within normal limits. Finally, subjects were alert, attentive, and cognitively intact.

(A) Spoken Discourse Samples

Subjects: Six subjects, three normal and three agrammatic speakers, participated in this task. All subjects were matched for age and Spanish dialect (i.e., Mexican, Puerto Rican, and Venezuelan).

Procedures: Following a format similar to the one used by the Cross-Language Agrammatism Group (Menn \& Obler, 1990), subjects were asked to describe the Cookie Theft picture of the BDAE, provide a rendition of a popular folktale ("Little Red Riding Hood"), and participate in conversation regarding their routine activities before their CVA.

Data Analysis: All subjects' utterances were audiotaped and transcribed, and the verbs were transcribed by speech/language professionals, all native speakers of the subjects' Spanish dialect. All intelligible verb utterances were included in the analysis. When literal paraphasias were produced (e.g, "sememos" for "comemos"), the analysis focused on the integrity of their inflections. All verb forms were tallied for each verb tense generated by the subjects. Percentages were calculated with the numerator representing the total number of times the verb form was employed by all agrammatic speakers and the denominator representing the total number of verb forms employed in their narratives (Table 1). 
(B) Sentence Repetition Task ${ }^{7}$

Subjects: Twelve Venezuelan subjects, six normal and six agrammatic speakers, participated in this task. Both subject groups were matched for age and Venezuelan Spanish dialect.

Procedures: Each subject was asked to repeat 216 audiotaped sentences divided into three 72 -sentence blocks to prevent their fatigue. The sentences consisted of 36 for each of the 6 verb tenses found in daily discourse (i.e., 36 sentences $\times 6$ verb tenses $=216$ sentences ). These sentences were constructed to have an equal number of verbs for each thematic vowel (see "Discourse Features of Spanish Verbs"), have a short SVO structure, and contain the verb tenses found in daily discourse: presente $\left(\mathrm{P}^{4}\right)$, preterito perfecto simple (PR), pretérito imperfecto (PRI), condicional $(C)$, pretérito perfecto compuesto (PRP), and pretérito pluscuamperfecto (PRC) (Bentivoglio, 1983; Bentivoglio \& Sedano, 1992; Silva-Corvalán, 1983). All verbs were high frequency (Márquez-Villegas, 1975), concrete, regular, transitive, and short in structure (i.e., 2syllable infinitive).

Data Analysis: a format similar to the one described for spoken agrammatic samples above was employed. In this case, all verb forms were tallied for each verb tense repeated correctly by the subjects. Percentages were calculated with the numerator representing the total number of times the target verb form was repeated correctly by all agrammatic subjects and the denominator representing the total number of stimuli for each verb tense presented to the six subjects for repetitions (i.e., 36 sentences for each verb tense $\times 6$ subjects $=216$ sentences) $($ Table 1$)$.

Table 1: Production of Verb Tenses by Normal and Agrammatic Spanish Speakers

\begin{tabular}{|c|c|c|c|}
\hline & $\longdiv { \text { NORMAL } }$ & AGRAMM & AATIC \\
\hline Verb Tense & $\begin{array}{l}\text { Newspapers + Soap Operas } \\
(\%)\end{array}$ & \begin{tabular}{|l} 
Spoken \\
Discourse \\
$(\%)$ \\
\end{tabular} & \begin{tabular}{|l} 
Sentence \\
Repetition \\
$(\%)$ \\
\end{tabular} \\
\hline PRESENTE (P) & $\begin{array}{l}53.5 \\
(265 / 495) \\
\end{array}$ & $\begin{array}{l}92.8 \\
(26 / 28) \\
\end{array}$ & $\begin{array}{l}59.2 \\
(128 / 216) \\
\end{array}$ \\
\hline $\begin{array}{ll}\text { PRETÉRITO } & \text { PERFECTO } \\
\text { SIMPLE (PR) } & \\
\end{array}$ & $\begin{array}{l}25.4 \\
(126 / 495) \\
\end{array}$ & 0 & $\begin{array}{l}50 \\
(108 / 216)\end{array}$ \\
\hline $\begin{array}{l}\text { PRETÉRITO IMPERFECTO } \\
\text { (PRI) }\end{array}$ & $\begin{array}{l}4.8 \\
(24 / 495) \\
\end{array}$ & \begin{tabular}{|l|}
7.1 \\
$(02 / 28)$ \\
\end{tabular} & $\begin{array}{l}20.8 \\
(45 / 216) \\
\end{array}$ \\
\hline FUTURO (F) & $\begin{array}{l}1.2 \\
(06 / 495)\end{array}$ & 0 & * \\
\hline CONDICIONAL (C) & $\begin{array}{l}3.2 \\
(16 / 495) \\
\end{array}$ & 0 & $\begin{array}{l}19.9 \\
(43 / 216)\end{array}$ \\
\hline $\begin{array}{l}\text { PRETÉRITO PERFECTO } \\
\text { COMPUESTO (PRP) }\end{array}$ & $\begin{array}{l}4.4 \\
(22 / 495) \\
\end{array}$ & 0 & $\begin{array}{l}9.7 \\
(21 / 216) \\
\end{array}$ \\
\hline $\begin{array}{l}\text { PRETÉRITO } \\
\text { PLUSCUAMPERFECTO (PRC) }\end{array}$ & $\begin{array}{l}1.6 \\
(08 / 495)\end{array}$ & 0 & $\begin{array}{l}2.3 \\
(05 / 216) \\
\end{array}$ \\
\hline $\begin{array}{l}\text { CONDICIONAL PERFECTO } \\
\text { (CP) }\end{array}$ & $\begin{array}{l}0.4 \\
(02 / 495)\end{array}$ & 0 & * \\
\hline
\end{tabular}


The percentages shown indicate the number of times that a verb form was produced by the speaker. Verb tenses that were not produced $(0)$ or not employed in this investigation ${ }^{*}$ ), since they did not occur in normal daily discourse (Bentivoglio, 1983; Bentivoglio \& Sedano, 1992; Silva-Corvalán, 1983), are also shown.

\section{Results and Discussion}

Regarding normal discourse in the current study, the present tense, presente (e.g. yo como [1 eat]), was the most frequently employed verb form followed by the preterite, pretérito perfecto simple (e.g. yo comi [I eat]). All other verb tenses occurred minimally in the samples (Table 1).

In terms of the agrammatic speakers, we had predicted that those verb tenses most prominently used in normal conversation in Spanish, that is, the present and the preterite (Silva-Corvalán, 1983), would be more likely to be employed by agrammatic speakers in their verb attempts. Indeed, as in normal speakers, the presente consistently was the most frequently used tense by the agrammatic subjects. The preterito perfecto simple, the second most frequent tense in normal speakers, was similarly employed correctly by agrammatic subjects in the repetition task but was not present in their discourse despite the fact that it could have been used for the stimuli given. All other verb tenses, minimally found in normal texts, were similarly never produced in agrammatic discourse or minimally produced correctly in agrammatic sentence repetition.

These results suggest that daily verb use patterns have a facilitating effect on verb use by agrammatic speakers. They also agree with earlier arguments supporting the resistance of high-frequency words to errors in normal and aphasic speakers (Goodglass, 1976; Hall 1954; Howes, 1964; Miceli \& Caramazza, 1988; Rochford \& Williams, 1965; Stemberger, 1984), possibly a reflection of an automatic, routinized, and overlearned nature due to their early acquisition (Schnitzer, 1989) and a significant degree of lexical strength (Bybee, 1985; 1995; Stemberger \& MacWhinney, 1986).

In sum, agrammatic verb profiles for Spanish speakers are similar to those reported for speakers of other Romance languages, such as French and Italian, with a similar degree of inflectional complexity in their verb systems (De Bleser \& Luzzatti; 1994; Jarema \& Kehayia, 1992; Nespoulous et al., 1989; Tissot et al., 1973). As in French and Italian agrammatism, verb use by agrammatic Spanish speakers can be characterized by a reliance on a limited repertory of simple verb forms, such as the infinitive and the imperfect, at the expense of other verb forms requiring more complex inflectional markings to encode the different morphosyntactic and semantic features of Spanish verbs (Centeno, 1996). Yet, the complex inflectional paradigm of Spanish verbs allowed us to investigate the possible correlations between pre-morbid verb use in spoken discourse and agrammatic verb production, an interaction not studied in earlier investigations on agrammatism. Our findings, supporting a possible facilitating role of frequency of verb use in daily oral discourse in verb production by agrammatic Spanish speakers, provide a plausible account that might likely hold for agrammatic verb production in other languages, and probably beyond the verb system, as well. 


\section{Footnotes}

'A version of this paper was presented at the $5^{10}$ Congreso Latinoamericano de Neuropsicología, Guadalajara, Mexico, October, 1997; and will be published in Matute, E., \& Leal, F. (In preparation). Introducción al Estudio del Español desde una Perspectiva Multidisciplinaria. México: Fondo de Cultura Económica y Universidad de Guadalajara.

${ }^{2}$ In general terms, Givón (1979), looking at language from a phylogenetic and ontogenetic point of view, describes a communicative continuum consisting of three levels; a monopropositional level, restricted to time and space and associated with concrete concepts; a pragmatic level, involving conversational interpretation of sentences, and a syntactic level, responsible for morphosyntactic language descriptions.

${ }^{3}$ Tenses have been labeled using the terminology of the Real Academia Española (1985), RAE.

${ }^{4}$ Abbreviations (P, PR, PRI, ctc.; see Appendix A) are only given for those verb forms that are used in the experimental stimuli of this study.

${ }^{5}$ The inflected form of the future (e.g., comere [will eat]), rather than its periphrastic form (e.g., ir a comer [going to eat]), is shown on this table since the inflected form is the one receiving morphological markings.

${ }^{6}$ The verb conjugations provided are only for those tenses included in this investigation.

${ }^{7}$ The data presented here were analyzed differently in an earlier and larger investigation of verb use by Spanish-speaking agrammatic subjects (Centeno, 1996).

Address correspondence to: José G. Centeno, Ph.D., New York Speech Pathology Clinic, 145 East 15th St., New York, NY 10003, U.S.A. E-mail: frontier2(a)mindspring.com

\section{References}

Ardila, A. (2001). The manifestation of aphasic symptoms in Spanish. In M. Paradis (Ed.), Manifestations of aphasic symptoms in different languages. Oxford: Pergamon Press.

Bentivoglio, P. (1987). Los sujetos pronominales de primera persona en el habla de Caracas. Caracas: Universidad Central de Venezuela.

Bentivoglio, P., \& Sedano, M. (1992). Morfosintaxis. In A. Alvarez, P. Bentivolgio, E. Obediente, \& M. Sedano, M.J. Tejera (Eds.), Fl idioma Español de la Venezuela actual. Caracas: Lagoven.

Bybce, J. (1985). Morphology: A study of the relation between meaning and form. Amsterdam: John Benjamins.

Bybee, J. (1995). Regular morphology and the lexicon. Language and Cognitive Processes, 10 , 425-455.

Centeno, J. (1996). Use of verb inflections in the oral expression of agrammatic Spanish-speaking aphasics. Unpublished doctoral dissertation, City University of New York

De Bleser, R., \& Luzzatti, C. (1994). Morphological processing in Italian agrammatic speakers' syntactic implementation of inflectional morphology. Brain and Language, 46, 21-40.

Garrett, M.F. (1980). Levels of processing in sentence production. In B. Butterworth (Ed.), Language Production, vol. 1. London: Academic Press. 
Garrett, M.F. (1975). The analysis of sentence production. In G. Bower (Ed.), Psychology of Learning and Motivation, vol. 9. New York: Academic Press.

Givón, T. (1979). On understanding grammar. New York: Academic Press.

Gonzalez, G. (1980). The acquisition of verb tenses and temporal expressions in Spanish children age 2.0 to 4.6. Bilingual Education Paper Series, 4(2).

Goodglass, H.(1973). Studies on the grammar of aphasics. In H. Goodglass \& S. Blumstein (Eds.), Psycholinguistics and aphasia. Baltimore: John Hopkins University Press.

Goodglass, H. (1976). Agrammatism. In H. Whitaker \& H. A. Whitaker (Eds.), Studies in Neurolingistics, vol. 1. New York: Academic Press.

Goodglass, H., \& Kaplan, E. (1974). Evaluación de la afasia y de trastornos similares. (Translated by Sylvia Cuschnir de Fairman). Buenos Aires: Editorial Médica Panamericana.

Grodzinsky, Y. (1990). Theoretical perspectives on language deficits. Cambridge, MA: MIT Press.

Hall, J.F. (1954). Learning as a function of word frequency. American Journal of Psychology, 67, $138-140$.

Howes, D. (1964). Application of the word frequency concept to aphasia. In A.V.S. DeReuck \& M. O'Connor (Eds.), Disorders of language. London: Churchill

Jarema, G., \& Kehayia, E. (1992). Impairment of inflectional morphology and lexical storage. Brain and Language, 43, 541-564.

Jarema, G., \& Nespoulous, J.-L. (1984). Infinitif et flexions verbales chez l'aphasique agrammatique. La Linguistique, 20 (Fasc. 2), 99-113.

Kvaal, J.T., Shipstead-Cox, N., Nevitt, S.G., Hodson, B.W., \& Launer, P.B. (1988). The acquisition of 10 Spanish morphemes by Spanish-speaking children. Language. Speech, and Hearing Services in Schools, 19, 384-394.

Maéz, L.F. (1981). Spanish as a first language: The early stages. Unpublished doctoral dissertation, University of California, Santa Barbara, CA.

Marcos-Marín, F. (1975). Aproximación a la gramática Española. Madrid: Cincel.

Marquéz-Villegas, L. (1975). Vocabulario del Español Hablado. Madrid: Sociedad General Española de Librcría.

Menn, L., \& Obler, L.K.(1990). Agrammatic aphasia, vol. 1-3. Amsterdam: John Benjamins.

Miceli, G., \& Caramazza, A. (1988). Dissociation of inflectional and derivational morphology. Brain and Language, 35, 24-65.

Miceli, G., \& Mazzucchi. (1989). Agrammatism in Italian: Two case studies. In L. Menn \& L.K. Obler (Eds.), Agrammatic aphasia, vol. 1. Amsterdam: John Benjamins.

Nespoulous, J-L., Dordain, M., Perron, C., Jarema, G., \& Chazal, M. (1989). Agrammatism in French: two case studies. In L. Menn \& L.K. Obler (Eds.), Agrammatic aphasia, vol. 1. Amsterdam: John Benjamins.

Obler, L. K., Harris, K., Meth, M., Centeno, J., \& Matthews, P. (1999). The phonologymorphosyntax interface: Affixed words in agrammatism. Brain and Language, 68, 233-240.

Qüilis, A., \& Hernández-Alonso, C. (1990). Lingüistica Española aplicada a la terapia del lenguaje. Madrid: Gredos.

Real Academia Española. (1985). Esbozo de una gramática de la Lengua Española. Madrid: Espasa-Calpe.

Reznik, M., Dubrovsky, S., \& Maldonado, S. (1995). Agrammatism in Spanish: A case study. Brain and Language, 51, 355-368.

Rochford, G., \& Williams, M. (1965). Studies in the development and breakdown of the use of names. IV: The effect of word frequency. Journal of Neurology, Neurosurgery, and Psychiatry. 28, 407-413.

Schnitzer. M.L. (1989). The pragmatic basis of aphasia. Hillsdale, NJ: Lawrence Erlbaum.

Sebastián, E., \& Slobin, D. (1994). Development of linguistic forms: Spanish. In R. A. Berman \& D. I. Slobin (Eds.), Relating events in narrative: A crosslinguistic developmental study. 
Hillsdale, NJ: Lawrence Erlbaum.

Sedano, M. (In press). El futuro morfológico y la expresión ir a + infinitivo en el Español hablado de Venezuela. Verba.

Silva-Corvalán, C. (1983). Tense and aspect in oral Spanish narrative. Language, 59, 760-780.

Stemberger, J.P. (1984). Structural errors in normal and agrammatic speech. Brain and Language, l, 281-313.

Stemberger, J.P., \& MacWhinney, B. (1986). Frequency and the lexical storage of regularly inflected forms. Memory and Cognition, 14, 17-26.

Stockwell, R.P., Bowen, J.D., \& Martin, J.W. (1965). The grammatical structures of English and Spanish. Chicago: University of Chicago.

Tissot, R.J., Mounin, G., \& Lhermitte, F. (1973). L'agrammatisme. Brussels: Dessart. 


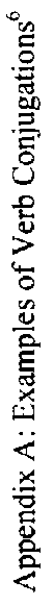

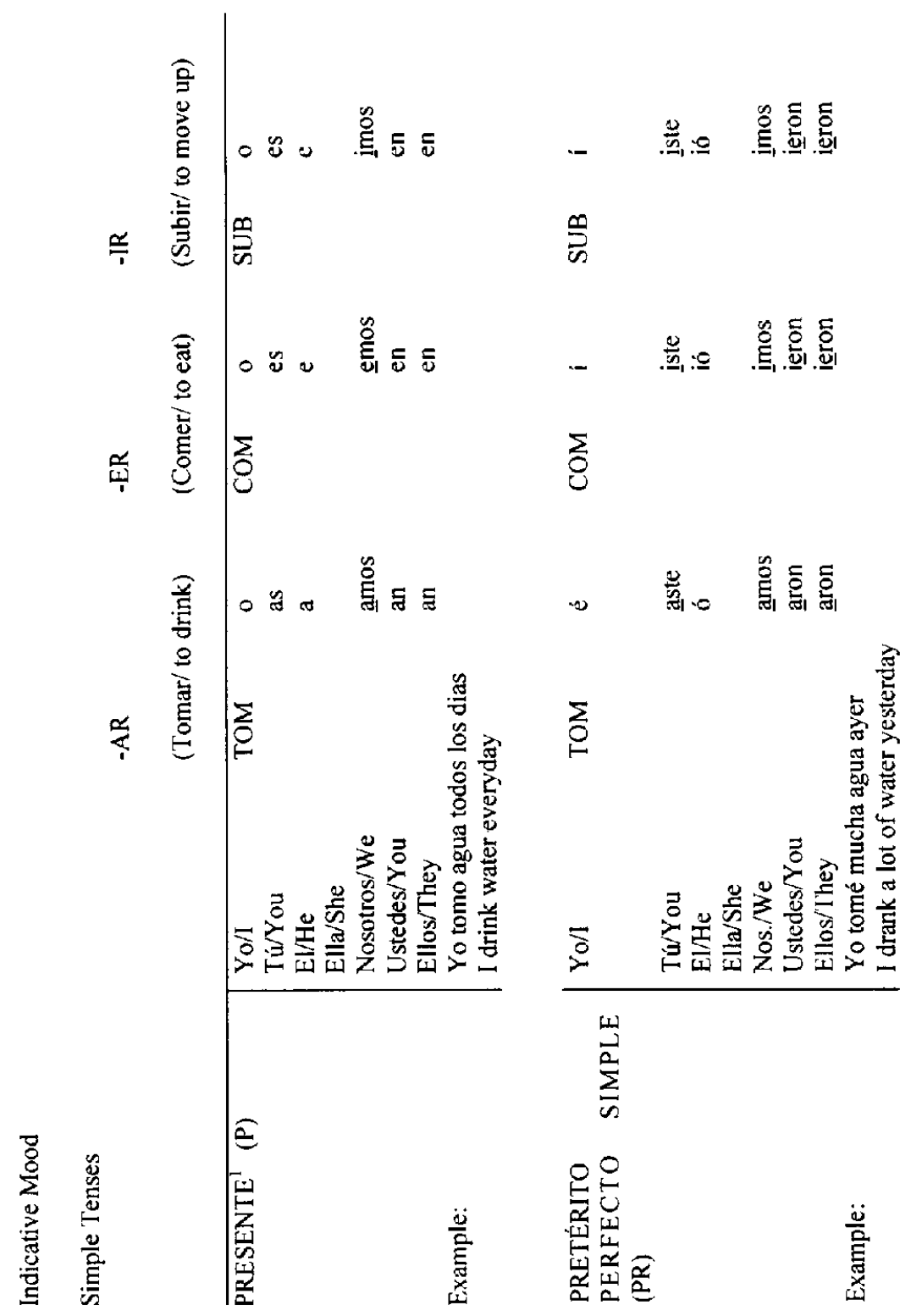




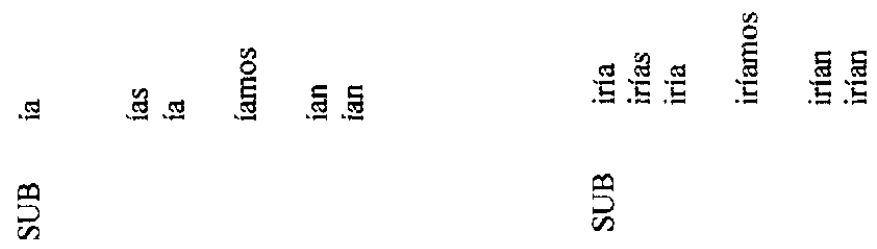
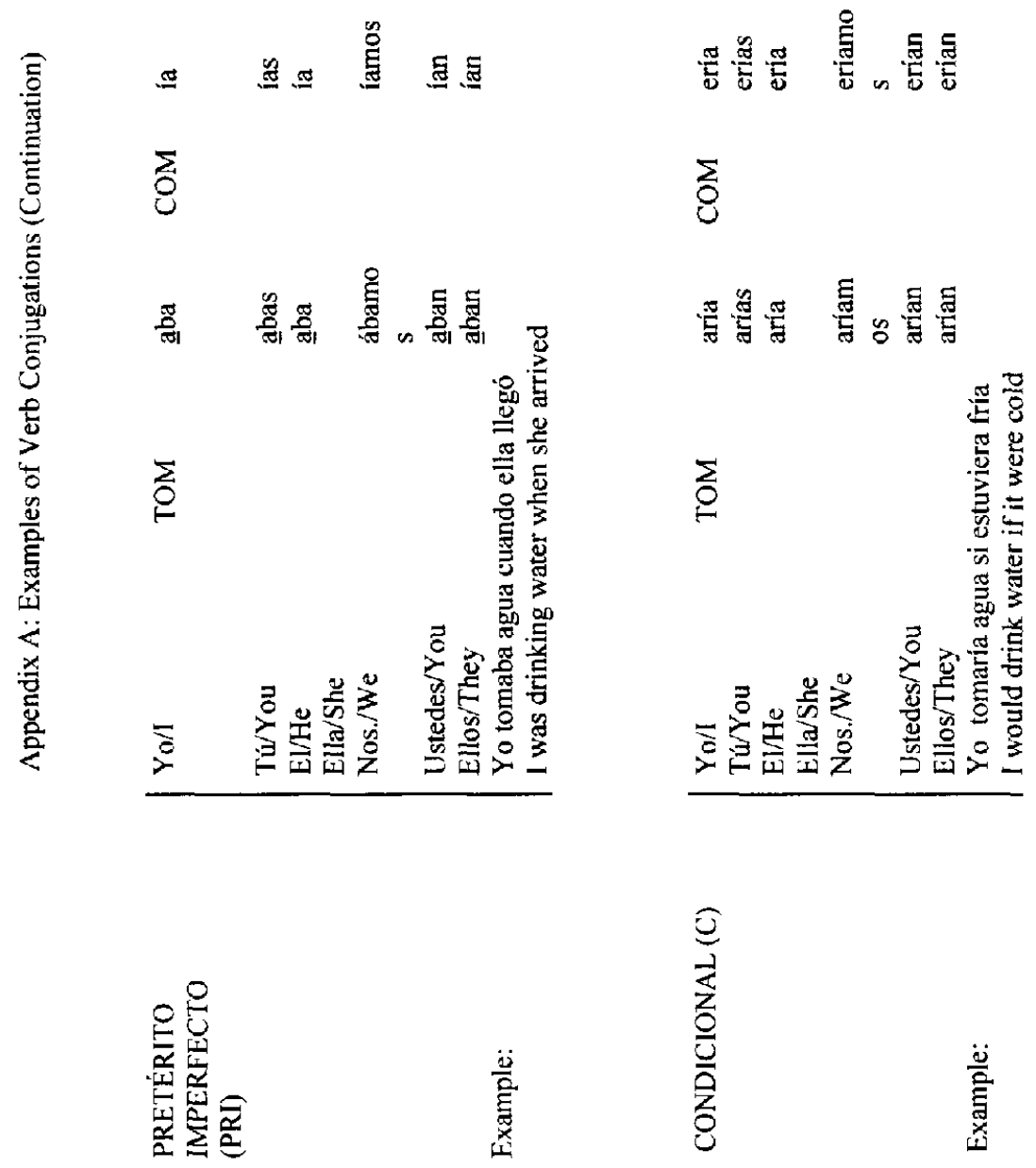

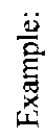

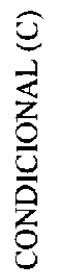

㒸 


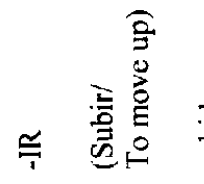

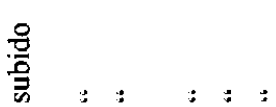

尊 : : : : :

冚

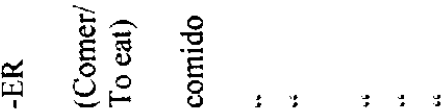

过

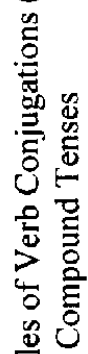

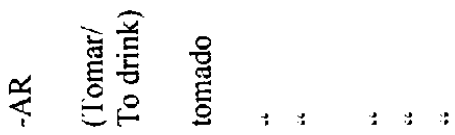

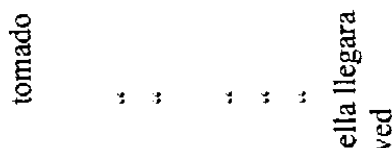

ะ 峞

हํㅡㄹ 로음 过

う
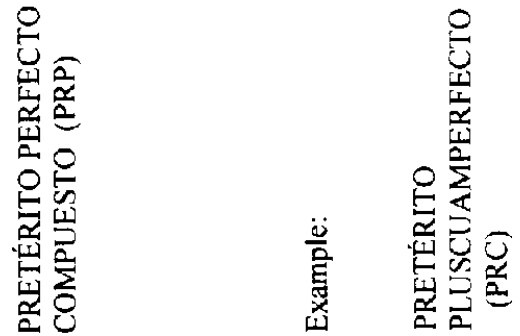

总 